\title{
Evaluation of Biosecurity Implementation in Layer Chicken Farm in Gulurejo Village, Lendah Subdistrict, Kulonprogo District
}

\author{
Francy Risvansuna \\ Departement of Agribusiness \\ Universitas Muhammadiyah Yogyakarta \\ Yogyakarta, Indonesia \\ francy@umy.ac.id
}

\author{
Yus Peisal Nurhikmat \\ Departement of Agribusiness \\ Universitas Muhammadiyah Yogyakarta \\ Yogyakarta, Indonesia
}

\begin{abstract}
The unreasonable mortality rate of poultry in Gulurejo Village has become a major problem. Although breeders claimed they have applied Biosecurity system, the issue of poultry mortality still could not be resolved. This study aims to analyze the condition and success level of Biosecurity application in a poultry farm in GulurejoVillage. The condition refers to nine aspects which are sanitation of the poultry coops and surroundings, drinking and food place, vaccinations, handling of poultry feces, sick and dead poultry, quarantine, and traffic control in poultry coops. This study was done in Gulurejo Village, Lendah Subdistrict, Kulonprogo Regency. The census's method was selected. The analysis technique used a rating scale and Spearman correlation. The result of this study showed that the Biosecurity level of poultry farming was on a medium level. That condition was caused by farmers who paid little attention to Biosecurity system, especially in the sanitation of food place and traffic control aspects. On the other hand, farmers who applied Biosecurity system well paid adequate attention to vaccinations, handling of dead poultry and quarantine. With regard to the level of successful applications, $\mathbf{8 2 \%}$ of farmers were not successful in Biosecurity application because the mortality level was still high.
\end{abstract}

Keywords-Biosecuritylevel, layer poultry farming, technical analysis

\section{INTRODUCTION}

One type of farm that needs to be developed to meet the needs of the Indonesian people is a laying hen farm. Demand for chicken eggs continues to increase from year to year. For the years of 2015-2017 the demand for chicken eggs in Indonesia is as follows: $100.88 \mathrm{~kg} /$ capita / year, $103.12 \mathrm{~kg}$ / capita / year and $110.19 \mathrm{~kg} /$ capita / year, respectively. Eventhough this business has considerable opportunities, laying hens have a high risk of failure due to disease attacks. Diseases that attacklaying hens are bird flu and Newcastle disease or commonly called Tetelo[1].

The effort currently being carried out on laying chicken farms is the application of a Biosecurity system in which the system aims to protect livestock from attacking diseases that can cause death. The application of Biosecurity systems to laying hen farming aims to avoid or protect chickens that are bred from various diseases[2]. Although, in a study in Cambodia, the application of basic Biosecurity was still unable to completely resolve the spread of diseases caused by viruses such as Newcastle disease virus or Tetelo disease[3].

One region that has implemented a Biosecurity system since 2014 is Gulurejo village in Kulonprogo Regency. This area is a laying hens farm center. All laying poultry farms in Gulurejo Village are small-scale farms that are under 10,000 heads. Nonetheless, in 2015, hundreds of chickens died suddenly due to the laying hens infected by tetelo. This caused the farmers to experience considerable losses. Therefore, an evaluation is needed regarding the implementation of the Biosecurity system that has been carried out in the region.

\section{METHODS}

This research was conducted in Gulurejo Village, Lendah Subdistrict, Kulonprogo District because the area is a center for laying hens. Determination of respondents of census method. To measure the application of a Biosecurity system a rating scale was used, while to see the relationship between the application of a Biosecurity system and the mortality rate, correlation analysis usedwas Spearman.

\section{RESULTS AND DISCUSSION}

Application of Biosecurity System in Layer Chicken Farming in Gulurejo Village

Application of Biosecurity system was observed from nine aspects, namely cleanliness of the enclosure and its environment, cleanliness of the drinking place, cleanliness of the feed, vaccinations, handling of manure, handling of sick chickens, handling of dead chickens, quarantine actions and application of traffic control.

\section{Cleanliness of the Enclosure and the Environment}

Table 1. Assessment of the Cleanliness Condition of Cages and Environment in Layer Chicken Farms

\begin{tabular}{lccc}
\hline \multirow{2}{*}{$\begin{array}{c}\text { Assessment } \\
\text { Criteria }\end{array}$} & Good & Medium & Bad \\
\cline { 2 - 4 } Hygiene Conditions & 0 & 26 & 9 \\
Use of Disinfectants & 60 & 0 & 2 \\
Kurun Cleaning Time & 9 & 20 & 9 \\
\hline
\end{tabular}

$\begin{array}{lc}\text { Total Score } & 135 \\ \text { Information } & \text { Moderate }\end{array}$

Assessment criteria for cleanliness condition of the enclosure and the environment include hygiene condition, use of disinfectants, and cleaning periods. 
The condition of the cleanliness of the enclosure and its environment for laying hens in the village of Gulurejowas moderate. This medium condition indicated that farmers did not fully carry out Biosecurity, especially on the cleanliness aspect of the cage and its environment.

\section{Cleanliness of Drinking Places}

Assessment criteria on the aspect of cleanliness of drinking places include hygiene condition, periods of washing time and use of disinfectants.

Table 2. Assessment of Drinking Conditions in Laying Hens in Gulurejo Village in 2017

\begin{tabular}{lccc}
\hline \multirow{2}{*}{$\begin{array}{c}\text { Assessment } \\
\text { Criteria }\end{array}$} & Good & Medium & Bad \\
\cline { 2 - 4 } & 51 & 8 & 1 \\
\hline Hygienic Condition & 60 & 0 & 2 \\
Use of Disinfectant & 51 & 6 & 2 \\
Cleaning Time & \multicolumn{3}{|c}{} \\
\hline Total Score & \multicolumn{3}{c}{ Moderate } \\
Categories & &
\end{tabular}

Table 2 shows the scores obtained from the results of an assessment of the condition of livestock drinking places. The score obtained was 181, which indicateda moderate condition of the cleanliness of the drinking place. This condition indicated that there were some aspects that were not properly considered or implemented in the drinking condition. In addition, the medium condition was an accumulative result of three aspects of assessment of the variety of drinking conditions, namely hygiene conditions, the use of disinfectants and the cleaning period of drinking places.

\section{The Condition of the Place of Feeding}

Cleanliness of the feeding place was assessed from the cleanliness conditions, the period of washing time and the use of disinfectants.

Table 3. Assessment of Feed Site Conditions in Layer Chicken Farms in Gulurejo Village in 2017

\begin{tabular}{lccc}
\hline \multicolumn{1}{c}{$\begin{array}{c}\text { Assessment } \\
\text { Criteria }\end{array}$} & \multicolumn{3}{c}{ Score } \\
\cline { 2 - 4 } & Good & Medium & Bad \\
\hline Cleanliness Condition & 6 & 34 & 3 \\
Use of Disinfectant & 60 & 0 & 2 \\
Cleaning Time & 0 & 10 & 17 \\
\hline Total score & \multicolumn{3}{|c|}{ Medium } \\
Category & \multicolumn{3}{c}{} \\
\hline
\end{tabular}

Based on table 3 it can be seen that the score of the feeding place was 132 which indicateda moderate condition. This condition was due to farmers' lack of attention to the condition of the feeding place and proper ways of its cleaning, especially during the cleaning period. This condition was an accumulative result of hygiene condition, use of disinfectants and cleaning periods.

\section{Vaccination}

Aspects of vaccination in this study will be seen from how the vaccine is given by farmers to their livestock chickens.

The score obtained from the assessment of aspects of vaccination implementation is 62 which means that the implementation is in good condition. Vaccination of livestock in the village of Gulurejo is mostly $91 \%$ carried out by officers of the livestock department. Meanwhile, there are farmers who do not vaccinate. Vaccination is carried out on livestock, chickens to prevent the attack of the chicken from various diseases. Vaccination carried out in the right dosage and manner that is appropriate to the age conditions will have a good impact on the condition of the chicken itself[4].

Table 4. Assessment of Implementation of Vaccination in Layer Chicken Farms in 2017 Gulurejo Village

\begin{tabular}{lccc}
\multicolumn{1}{r}{$\begin{array}{c}\text { Criteria } \\
\text { Ratings }\end{array}$} & \multicolumn{3}{c}{ Score } \\
\cline { 2 - 4 } & Good & Average & Poor \\
\hline $\begin{array}{l}\text { Implementation of } \\
\text { vaccination }\end{array}$ & 60 & 0 & 2 \\
Total Score & & $\mathbf{6 2}$ & \\
Category & & Good \\
\hline
\end{tabular}

\section{Handling Livestock Manure}

Handling method and handling time oflivestock manure were the assessment criteria in this research on the aspect of livestock manurehandling.

Table 5 provides an overview of the conditions in how the manure were laid on laying hens in Gulurejo Village. The score obtained was 97 which indicateda moderate condition. From the table, it can be seen that the farmers handled livestock dung well. However, the time aspect of the removal of dirt from the cage was mostly in poor condition. The aspects that were assessed were the handling method and the time of cleaning the dirt from the cage.

Table 5. Assessment of Livestock Manure Handling on Ranch Broiler Laying in the village Gulurejo 2017

\begin{tabular}{lccc}
\hline \multicolumn{1}{c}{$\begin{array}{c}\text { Assessment } \\
\text { Criteria }\end{array}$} & Good & Average & Poor \\
\cline { 2 - 4 } & 66 & 0 & 0 \\
Handling & 0 & 18 & 13 \\
Time Period & \multicolumn{3}{c}{ 97 } \\
\hline Total score & \multicolumn{3}{c}{ Average } \\
Category & \multicolumn{3}{c}{} \\
\hline
\end{tabular}

\section{Chicken Handling Sick}

Assessment of handling sick chickens was seen from how the farmers handled sick chickens. Data regarding the handling condition of sick chickens can be seen in the table 6.

The score obtained was 48 which indicated the condition in handling dead chickens was moderate. This assessment 
observed the way farmerstook care of sick chickens. $18 \%$ of farmers handled sick chickens well by separating sick chickens from healthy chickens and treating them appropriately. Meanwhile, $82 \%$ did not perform the treatments of separating sick chickens from healthy chickens. Diseased chickens need to be handled specifically so that there will be no transmission diseases to other healthy chickens. Sick chickens must be placed in a closed room without contact with other livestock chickens[5]. Added that sick chickens should be kept away or placed in quarantine cages that are separated from healthy chicken coops[6].

Table 6. Assessment of Pain Management at the Chicken Ranch Chicken Laying in the village of RasGulurejo 2017

\begin{tabular}{lccc}
\multicolumn{1}{c}{$\begin{array}{c}\text { Assessment } \\
\text { Criteria }\end{array}$} & \multicolumn{3}{c}{ Score } \\
\cline { 2 - 4 } & Good & Average & Poor \\
\hline Handling & 12 & 36 & 0 \\
Total score & \multicolumn{3}{c}{$\mathbf{4 8}$} \\
Category & \multicolumn{3}{c}{ Medium } \\
\hline
\end{tabular}

\section{Handling of Dead Chicken}

Assessment of handling dead chickens was seen from how the farmers handleddead chickens.

Table 7. Assessment on Livestock Handling Dead Chickens Broiler Laying in Gulurejo Village2017

\begin{tabular}{lccc}
\hline \multicolumn{1}{c}{$\begin{array}{c}\text { Criteria for } \\
\text { Evaluation of }\end{array}$} & Good & Medium & Poor \\
\cline { 2 - 4 } & 66 & 0 & 0 \\
\hline Handling Method & & $\mathbf{6 6}$ & \\
Total Score & & Good & \\
Category & &
\end{tabular}

The score obtained was 66 , which indicated that the farmers' handling of dead chickens was in good condition. This could be seen from the way of handling dead chickens. All breeders in the village of Gulurejo immediately took dead chickens for burning or burial of the dead chickens. Dead chickens need to be burned to avoid contracting the disease to other livestock that are still healthy and become a source of very harmful diseases[7].

\section{Quarantine Action on New Chickens}

Quarantine action condition was determined by how and how long new chickens were placed separately from existing livestock chickens.

Table 8. Handling of Quarantine Measures in Laying Hens

\begin{tabular}{lccc}
\multicolumn{1}{c}{$\begin{array}{c}\text { Assessment } \\
\text { Criteria }\end{array}$} & \multicolumn{3}{c}{ Score } \\
\cline { 2 - 4 } & Good & Medium & Bad \\
\hline Quarantine Action & 66 & 0 & 0 \\
Total Score of & & $\mathbf{6 6}$ & \\
Categories & \multicolumn{3}{c}{ Good } \\
\hline
\end{tabular}

The score obtained from treating new chickens was 66, which indicated that the condition was good. All breeders quarantine new chickens so that they were not directly mixed with old or pre-existing chickens. Quarantine actions on new chickens need to be done in an effort to prevent transmission of diseases. New farm animals have the potential to bring viruses and need to be separated without prior contact with existing livestock chickens[5].

Assessment of traffic control conditions was seen from the application of traffic control carried out by farmers.

The score obtained from the application of traffic control was 30 which indicated that the condition was bad. There was only a makeshift fence that was used as a barrier so that no other animal could enter. The number of farmers who applied traffic control was $36 \%$. The same is true for broiler chicken farmers in China. Only $47 \%$ of farmers-controlled traffic by controlling wild birds and rodents so they could not enter their farms. Birds and wild rodent animals can be an intermediary for the infection of chickens, so that livestock can be infected with the virus[8]. Farmers need to avoid direct contact between livestock, chickens with sources or carriers of disease. This method is done by limiting contact between humans, equipment used and other animals[9].

Table 9. Assessment of Traffic Control on Ranch Broiler Laying in the village Gulurejo 2017

\begin{tabular}{lccc}
\hline \multirow{2}{*}{ Assessment Criteria } & \multicolumn{3}{c}{ Score } \\
\cline { 2 - 4 } & Good & Average & Poor \\
\hline Application Traffic Control & 0 & 16 & 14 \\
Total Score & \multicolumn{3}{c}{$\mathbf{3 0}$} \\
Category & \multicolumn{3}{c}{ Recent } \\
\hline
\end{tabular}

\section{Implementation of the Overall Biosecurity System}

After the assessment of each aspect of Biosecurity levels in laying poultry farms was observed and analyzed, the overall application of Biosecurity system could be clearly seen.

The implementation of Biosecurity system in general for laying chicken farms in Gulurejo Village was in moderate condition. $44 \%$ of the application of Biosecurity system was in a good condition which included aspects of the cleanliness of the enclosure and its environment, the implementation of vaccinations, handling dead chickens and quarantine actions. Meanwhile, $44 \%$ of the application of Biosecurity, was in a moderate condition which covered aspects of cleanliness of the drinking place, cleanliness of the feeding place, handling of livestock manure and handling of sick chickens. On the other hand, it was found that $12 \%$ of Biosecurity applications was in a bad condition which were found in the aspects traffic control application. This is also in line with research which states that poor traffic control, such as visitors coming too frequently or employees coming to the location of the farm without paying attention to cleanliness, will cause poultry to be more easily infected with the disease[10].

The application of Biosecurity system needs to be improved to reduce the rate of deaths caused by attacks of Tetelo disease. Biosecurity is a system that if implemented 
properly and maximally will prevent chickens from being attacked by disease and death[11].

Table 10. Assessment of overall Biosecurity on Poultry Ras Laying in the village ofGulurejo 2017

\begin{tabular}{lccc}
\hline \multicolumn{1}{c}{ BiosecurityAspect } & Score & $\begin{array}{c}\text { Percentage } \\
(\%)\end{array}$ & Category \\
\hline $\begin{array}{l}\text { Cleanliness condition of } \\
\text { the enclosure and }\end{array}$ & 135 & 68 & Medium \\
$\begin{array}{l}\text { environment } \\
\text { Condition of cleanliness } \\
\text { of drinking area }\end{array}$ & 181 & 91 & Moderate \\
$\begin{array}{l}\text { Condition of cleanliness } \\
\text { of the feeding area }\end{array}$ & 132 & 67 & Moderate \\
$\begin{array}{l}\text { Vaccination } \\
\text { Way of handling } \\
\text { chicken manure }\end{array}$ & 62 & 94 & Good \\
$\begin{array}{l}\text { Way of handling sick } \\
\text { chickens }\end{array}$ & 98 & 73 & Moderate \\
$\begin{array}{l}\text { How to handle dead } \\
\text { chickens? }\end{array}$ & 66 & 100 & Good \\
$\begin{array}{l}\text { Quarantine action } \\
\begin{array}{l}\text { Implementation of } \\
\text { traffic control }\end{array}\end{array}$ & 66 & 100 & Good \\
\hline $\begin{array}{l}\text { Total score and } \\
\text { Category }\end{array}$ & $\mathbf{8 1 7}$ & 45 & Poor \\
\hline
\end{tabular}

\section{Success Rate of Biosecurity System Implementation}

The success rate of implementing Biosecurity systems on laying chicken farms can be seen from the mortality rate. The better the implementation of Biosecurity systems by farmers, the lower the mortality rate of poultry.

Table 11. Mortality Rate of Laying Hens in Gulurejo Village 2017

\begin{tabular}{lcc}
\hline Mortality Rate $(\boldsymbol{\%})$ & Percentage $(\boldsymbol{\%})$ \\
\hline & $\leq 7$ & 18 \\
& $>7$ & 82 \\
\hline Total & $\mathbf{1 0 0}$ \\
\hline
\end{tabular}

The mortality rate of laying hens in the village of Gulurejo is quite high. In most of the farms (83\%), the chicken mortality rate is more than $7 \%$. The maximum standard of animal mortality rates that apply a Biosecurity system is $7 \%$ [12].Thus, the number of farmers who have successfully implemented Biosecurity system is only $18 \%$. Implementation of a better Biosecurity system will reduce the mortality rate of laying poultry farms. Farms that implement biosecurity systems well have a smaller risk of disease attacks[13]. To prove that the level of Biosecurity conditions affected the mortality rate, a Spearman correlation analysis was carried out.

The results of the Spearman correlation analysis showed that the better the implementation of the Biosecurity system, the lower the mortality rate of laying hens. This is more evident from the correlation coefficient number at -0.626 .

\section{CONCLUSION}

The overall Biosecurity implementation of laying hens in the Gulurejo Village is in moderate condition. This is because most farmers do not pay attention to sanitation aspects in the form of food hygiene and aspects of traffic control on their farms. In general, the application of Biosecurity on laying hens in the Gulurejo village can be said to have been unsuccessful. The level of application of Biosecurity is strongly related to the level of mortality in laying chicken farms in Gulurejo Village.

There needs to be attention and assistance from related parties to farmers in implementing Biosecurity system properly according to the existing guidelines, so that it can be implemented optimally to reduce the mortality rate of livestock as much as possible.

\section{ACKNOWLEDGMENT}

The research presented in this paper was part of a research grant under the Kemitraan research schemes and thank you to LP3M Universitas Muhammadiyah Yogyakarta for facilitating funding for this research. Last but not least, thank you to Yus Peisal for helping this research.

\section{REFERENCES}

[1] Nurcholis, D. Hastuti, dan B. Sutiono, "Tatalaksana Pemeliharaan Ayam Ras Petelur Periode Layer di Populer Farm Desa Kuncen Kecamatan Mijen Kabupaten Semarang," Mediagro, vol. 5, no. 2, pp. 38-39, 2009.

[2] U. Hadi, Pelaksanaan Biosecurity Pada Peternakan Ayam. Bogor: Facultas Kedokteran Hewan IPB, 2010.

[3] A. Connan, Flavie Luce Goutard, Davun Holl, Sok Ra, Aurelia Ponsich, Arnaud Tarantola, San Sorn, Sirenda Fong ., "Randomized cluster trials of the impact of Biosecurity measure on poultry health in backyard flocks," Vet. J., vol. 198, no. 3, pp. 649-655, 2013.

[4] Priyono, "Mengenal Berbagai Macam Cara Vaksinasi Pada Ternak Ayam Ras," 2009. [Online]. Available:

http://www.ilmupetaban.com/2009/10/mengenal-berbagai-macamcara-vaksinasi_15.html. Diakses: 29-Oct-2017].

[5] FFAO, "Pencegahan dan Pengendalian Flu Burung Pada Peternakan Unggas Skala Kecil,” www. fao.org, 2015.

[6] Y. Ambarwati, "Cara Agar Ayam Tidak Mudah Terkena Penyakit," 2016. [Online]. Available: https://hobiternak.com/7. [Diakses: 05Nov-2017].

[7] D. Setyono and M. Ulfah, 7 Jurus Sukses Menjadi Peternak Ayam Ras Pedaging. Jakarta: Penebar Swadaya, 2011.

[8] Z. Huang, A. Loch, C. Fundly, and J. min Wang, "Adoption of HPAI Biosecurity measures: The Chinese broiler industry," $J$. Integr. Agric., vol. 16, no. 1, pp. 181-189, 2017.

[9] F. Fauzi, Pasti Panen Telur. Klaten: HF, 2014.

[10] S. S. Van, S. Ribbens, E. Ducheyne, E. Goossens, and J. Dewulf, "Assessing Biosecurity practices, movements and densities of poultry sites across Belgium, resulting in different farm risk groups for the infectious disease introduction and spread," Prev. Vet. Med., vol. 4, no. 98, pp. 259-270, 2011.

[11] Sutomo, 99\% Gagal Beternak Ayam Petelur. Jakarta: Penebar Swadaya, 2016.

[12] K. Adnan, "Sanitasi Kandang Unggas,” 2015. [Online]. Available: http://dokterternak.com/2015/09/21/sanitasi-kandang-unggasbagian-pertama. [Diakses: 10-Nov-2017].

[13] Sadarman, A. Wahyuni, C. Tabbu, and S. Budhiarta, "Hubungan Antara Praktek Manajemen Pemeliharaan dengan Kejadian Avian Influenza pada Peternakan Ayam Pedaging di sektor 3 Milik Mitra PT. Duta Technovet di DIY Selama Satu Siklus Pemeliharaan.," Jurnal Peternakan, vol. 8, no. 1, p. 6, 2011. 